\title{
Ecosystem services as a boundary object for sustainability
}

Citation for published version (APA):

Abson, D. J., von Wehrden, H., Baumgärtner, S., Fischer, J., Hanspach, J., Härdtle, W., Heinrichs, H., Klein, A. M., Lang, D. J., Martens, P., \& Walmsley, D. (2014). Ecosystem services as a boundary object for sustainability. Ecological Economics, 103, 29-37. https://doi.org/10.1016/j.ecolecon.2014.04.012

Document status and date:

Published: 01/01/2014

DOI:

10.1016/j.ecolecon.2014.04.012

Document Version:

Publisher's PDF, also known as Version of record

Document license:

Taverne

Please check the document version of this publication:

- A submitted manuscript is the version of the article upon submission and before peer-review. There can be important differences between the submitted version and the official published version of record.

People interested in the research are advised to contact the author for the final version of the publication, or visit the DOI to the publisher's website.

- The final author version and the galley proof are versions of the publication after peer review.

- The final published version features the final layout of the paper including the volume, issue and page numbers.

Link to publication

\footnotetext{
General rights rights.

- You may freely distribute the URL identifying the publication in the public portal. please follow below link for the End User Agreement:

www.umlib.nl/taverne-license

Take down policy

If you believe that this document breaches copyright please contact us at:

repository@maastrichtuniversity.nl

providing details and we will investigate your claim.
}

Copyright and moral rights for the publications made accessible in the public portal are retained by the authors and/or other copyright owners and it is a condition of accessing publications that users recognise and abide by the legal requirements associated with these

- Users may download and print one copy of any publication from the public portal for the purpose of private study or research.

- You may not further distribute the material or use it for any profit-making activity or commercial gain

If the publication is distributed under the terms of Article $25 \mathrm{fa}$ of the Dutch Copyright Act, indicated by the "Taverne" license above, 
Surveys

\title{
Ecosystem services as a boundary object for sustainability
}

\author{
D.J. Abson ${ }^{\text {a,* }}$, H. von Wehrden ${ }^{\text {a }}$, S. Baumgärtner ${ }^{\text {a }}$, J. Fischer ${ }^{\text {a }}$, J. Hanspach ${ }^{\text {a }}$, W. Härdtle ${ }^{\text {a }}$, H. Heinrichs ${ }^{\text {a }}$, \\ A.M. Klein ${ }^{\mathrm{a}}$, D.J. Lang ${ }^{\mathrm{a}}$, P. Martens ${ }^{\mathrm{a}, \mathrm{b}}$, D. Walmsley ${ }^{\mathrm{a}}$ \\ ${ }^{a}$ Research Center Futures of Ecosystem Services (FuturES), Faculty of Sustainability, Leuphana University of Lüneburg, Scharnhorststraße 1, 21355 Lüneburg, Germany \\ ${ }^{\mathrm{b}}$ International Centre for Integrated Assessment E' Sustainable Development, Maastricht University, Kapoenstraat 2, 6211KW Maastricht, The Netherlands
}

\section{A R T I C L E I N F O}

\section{Article history:}

Received 6 December 2013

Received in revised form 4 April 2014

Accepted 15 April 2014

Available online 8 May 2014

\section{Keywords:}

Bibliographic analysis

Ecosystem services

Ethics

Multivariate statistics

Normative knowledge

Transformative knowledge

Sustainability

Systems knowledge

\begin{abstract}
A B S T R A C T
Ecosystem services research has become a major academic field, drawing in various academic disciplines, perspectives, and research approaches. The multifaceted concept of "ecosystem services" includes a normative component, which has strong implicit links to the notion of sustainability. Yet, how ecosystem services research relates to sustainability has received little attention. We reviewed the current state of research on ecosystem services, and examined whether the concept's original motivation has allowed it to act as an effective boundary object for the integration of the diverse knowledge related to sustainability. A full-text, multivariate statistical analysis of 1388 peer-reviewed publications on ecosystem services from 1997 to 2011 revealed a rapidly growing but fragmented body of research, which has emphasized the development of descriptive understandings of human-nature interactions. Future challenges for the ecosystem services concept include greater integration of currently fragmented knowledge domains and stronger engagement with the concept's normative foundations.
\end{abstract}

(C) 2014 Elsevier B.V. All rights reserved.

\section{Introduction}

Ecosystem services are directly or indirectly appropriated ecosystem structures, functions or processes that contribute to human well-being (MA, 2005). The notion of "nature's services" has been discussed in the academic literature since at least the 1970s (Westman, 1977). The introduction of the term "ecosystem services" in the early 1980s (Ehrlich and Ehrlich, 1981; Ehrlich and Mooney, 1983) subsequently inspired a rapidly growing body of peer-reviewed literature, as well as major research undertakings such as the Millennium Ecosystem Assessment (MA, 2005), The Economics of Ecosystems and Biodiversity (TEEB) (Kumar, 2010) and the newly formed Intergovernmental Platform on Biodiversity and Ecosystem Services (IPBES). Some 30 years after the coining of the term, with the concept increasingly moving from a heuristic model towards an explicit decision and policy tool (Bateman et al., 2013; de Groot et al., 2010; Engel et al., 2008; Kinzig et al., 2011; Maes et al., 2012), and with controversy on its utility rising in parallel (Norgaard, 2010; Schröter et al., 2014), it is timely to reflect on the development and future direction of this burgeoning field of science.

As a scientific concept, "ecosystem services" has two dimensions. First, it acts as a descriptive framework to characterize and explain the interdependencies of humans and natural systems (Balmford et al., 2011;

\footnotetext{
* Corresponding author. Tel.: + 4941316771975.

E-mail address: Abson@uni.leuphana.de (D.J. Abson).
}

Collins et al., 2011), typically without addressing the value-laden assumptions that may shape such analyses (Peterson et al., 2010). Second, ecosystem services is a normative concept (Callicott et al., 1999; Reyers et al., 2010) used to explicitly ascribe values (or value judgements) to different system states, usually to identify aspects of human-nature interactions that ought to be improved.

Early formulations of the notion of ecosystem services-as typified by the "rivet poppers" analogy (Ehrlich and Ehrlich, 1981)-related species loss to the long-term persistence of Earth's life support systems, and subsequently used the notion as means of increasing public interest in biodiversity conservation (Gómez-Baggethun et al., 2010). More recently, the notion of ecosystem services has been further popularized by highlighting the likely implications of changes to ecosystem functioning for human well-being (Costanza et al., 1997; Daily, 1997; de Groot, 1987; MA, 2005). These three normative concerns-system persistence, biodiversity conservation and enhanced human well-being-can be considered foundational in the formation and motivation of the ecosystem services concept (Chan et al., 2006; Costanza, 2000; Wilson and Howarth, 2002).

An explicit normative framework is required to consider and manage the relations and potential trade-offs amongst the multiple normative concerns associated with human interactions with ecosystems. We suggest that the concept of sustainability provides a suitable framework for such judgements (Gibson, 2006; Toman, 1994). Sustainability is an explicitly normative concept that encompasses notions of system persistence, as well as the just allocation of resources for the fulfilment of 
long-term human and non-human welfare (Dobson, 1998; Norton, 2005). The notion of sustainability can provide a framework for using the ecosystem services concept as tool for considering and managing societal obligations towards (i) the current generation of humans, (ii) future generations of humans and (iii) the natural environment.

Given its increasing appeal to politicians, policy makers and the public, the ecosystem services concept holds great promise to act as a boundary object for sustainability-that is, it can link policy makers and different scientific disciplines together via collaboration on a common task (Star and Griesemer, 1989). However, as ecosystem services research has developed, it has drawn in multiple academic disciplines with their own particular interests and approaches. Questions remain regarding how this multitude of approaches has influenced the framing and operationalization of the ecosystem services concept, and how this has influenced its relation to sustainability.

We reviewed the peer-reviewed literature on ecosystem services to assess (i) the extent to which the ecosystem services research is coalescing into a cohesive research domain; and (ii) how ecosystem services research contributes to different types of knowledge required for sustainability.

\section{Growth and Focus of Ecosystem Services Research}

We considered 2535 publications in our review. These were chosen based on the following criteria: (i) they were English language "articles" or "review publications" indexed in the Scopus database; (ii) they were published between 1997 and 2011; (iii) they contained the term "ecosystem service(s)" in the title, abstract or keywords; and (iv) they were cited on average at least once per year (hereafter termed "well cited"). The year 1997 was set as the earliest date because this was when the rapid growth in (self-identified) ecosystem services research began-following the highly influential book Nature's Services (Daily, 1997) and R. Costanza's work on the global value of ecosystem services (Costanza et al., 1997). We focused on well cited publications because we deemed them likely to have had the most influence in the development of the ecosystem services concept.

Of the 2535 publications initially identified, 819 were classified as "secondary focus" via a subjective analysis of their titles, abstracts and keywords. That is, they either used the ecosystem services concept as a buzzword (e.g. as a post hoc justification for the research), or ecosystem services was only a minor focus of the publication. During this initial screening, we also categorized papers into broad publication types based on a subjective reading of abstracts (Fig. 1).

To ascertain to what extent the growth in ecosystem services research represented a real increase in research effort in this field, rather than simply an artefact of the general increase in peer-reviewed publications altogether, the number of ecosystem services publications was corrected for publication growth in research fields reasonably to be expected to engage in ecosystem services research (Supplementary Materials Table S3). Having corrected for inflation based on a baseline year of 1997 , there was approximately a 27-fold increase in ecosystem services research between 1997 and 2011. Well cited publications with a primary focus on ecosystem services grew at a slower rate, with a 15 -fold increase in publications between 1997 and 2011 (Supplementary Materials Fig. S1). Through time, the ratio of empirical/modelling publications to discussion/theory publications has remained relatively constant. The proportion of interdisciplinary empirical publications relative to all ecosystem service publications has decreased through time (Fig. 1a, b).

\section{Clustering of Ecosystem Services Publications}

To move beyond a description of the growth of ecosystem services research and its categorization, we performed a bibliographic, fulltext, multivariate statistical analysis of the well cited peer-reviewed publications with a primary focus on ecosystem services. Of a potential 1716 well-cited papers with a primary focus on ecosystem services, 328 were excluded because of a lack of institutional access or because the publication was not available in machine-readable portable document format (PDF). This left 1388 publications for full-text analysis. All statistical analyses were carried out in R 2.15 (R Core Team, 2012).

First, we applied a stepwise, bottom-up filter to the complete list of abundant words within the full text of the 1388 analysed publications. Approximately 27,000 unique words appeared in more than $1 \%$ of the papers. Of these, we removed all words that did not provide conceptual information. First, all proper, collective and abstract nouns were removed. Second, adjectives, pronouns, articles, numbers and abbreviations that could not be identified immediately were removed. The
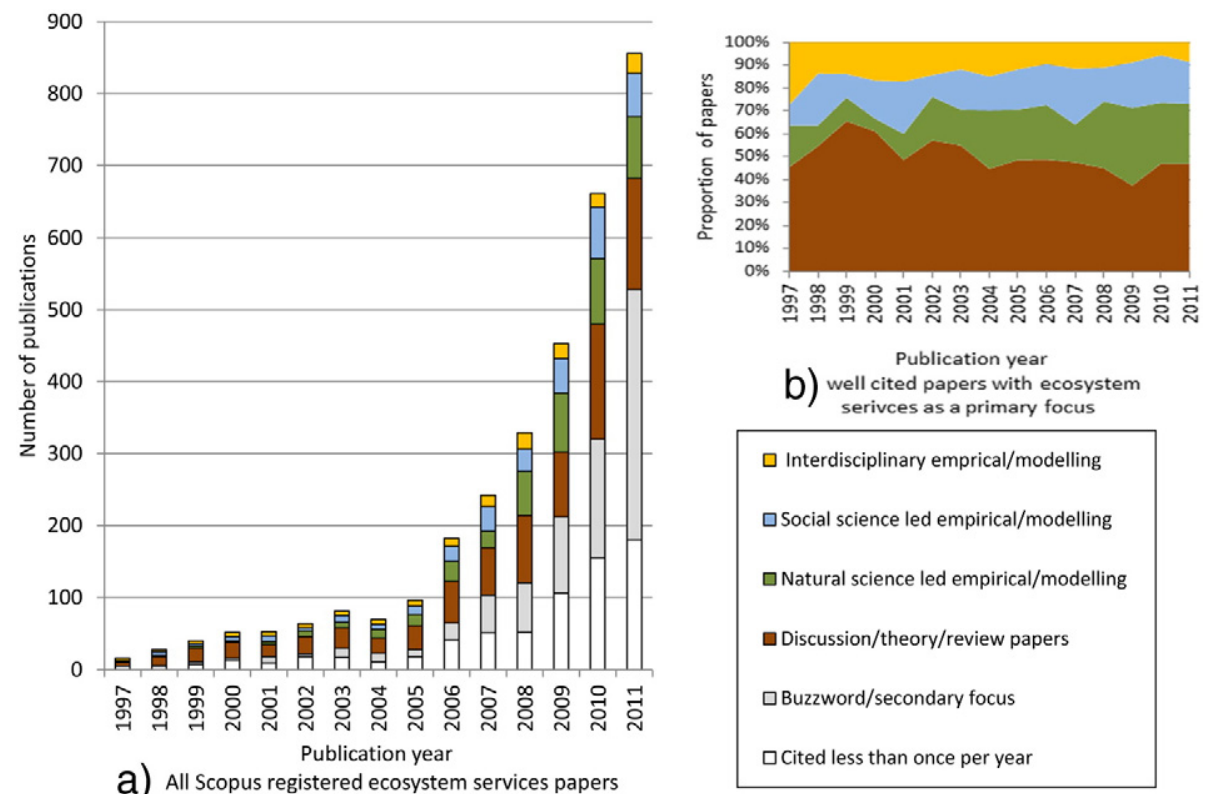

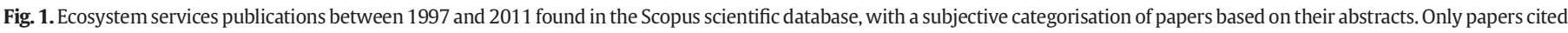

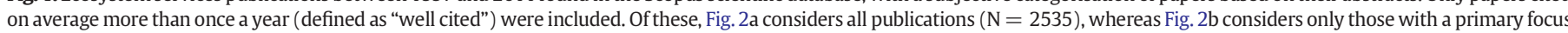
on ecosystem services (i.e. excluding buzzword usage; $\mathrm{N}=1716$ ). 
remaining list of words (approximately 4400) was further reduced, based on the meaning that could be inferred from individual words. For example, "valuation" was retained because it has a relatively clear meaning, whereas "running" was removed because it can be used in many completely different contexts. Words with potentially multiple meanings, such as "goal", which (for example) might relate to the goal of a given publication or to a societal goal, were also removed. The rationale was that publications approaching ecosystem services in different ways would use different conceptual vocabulary. We retained a "conceptual vocabulary" of 482 words, which were subsequently used to identify principle gradients in the "conceptual landscape" of ecosystem services publications. Within the multivariate matrix of conceptual keywords by publications, word abundance was scaled to text length of each publication to reduce a potential bias due to the different lengths of peer-reviewed articles within different disciplines.

We then used detrended correspondence analysis (DCA) of these words-with downweighting of rare words (function "decorana"; library "vegan")-to identify gradients in the vocabulary used in different papers (the first two axes had Eigenvalues of 0.32 and 0.24 respectively; Fig. 2a, b). The first ordination axis described a gradient from socialscience-driven research focusing on economic valuations and payments for ecosystem services; through management, conservation and governance research (centre); to natural science research dealing with traits, biodiversity and ecosystem functions and processes (Fig. 2a; x-axis). The second ordination axis ranged from research with immediate policy relevance (e.g. on payments for ecosystem services and pest management) to research with less immediate policy relevance (e.g. on ecological traits or biomass productivity).
We then performed an agglomerative hierarchical cluster analysis based on Euclidian distances using Ward's method (function "agnes"; library "cluster"). This method, taking into account all variables (i.e. relative abundances of conceptual keywords), starts by clustering single elements (i.e. publications) into aggregates of two elements based on the "minimum variance criterion". Next, it clusters the previous aggregates and continues until one cluster remains. The premise is to minimize within-group variance and maximize dissimilarities between groups. Ward's clustering was selected because it is widely used (and hence understood) and provided the most stable and informative clustering, yielding a high agglomerative coefficient and a relatively even distribution of cluster sizes.

An analysis similar in rationale to "indicator species analysis" in community (plant) ecology (Dufrene and Legendre, 1997) was then used to characterize each research cluster via significant indicator words (function "indval" with 1000 iterations to calculate probabilities; library "labdsv"). The most significant indicator word for a given cluster was used as the cluster label.

\subsection{Research Cluster Descriptions}

The cluster analysis identified nine distinct research clusters within the publications, with an agglomerative coefficient of 0.95 (Fig. 2a, c). Each cluster represented a group of publications with a strongly shared conceptual vocabulary. For ease of interpretation, we plotted only the most significant indicator words for each distinct research cluster in an ordination plot (see Table S4 in Supplementary Materials for a complete list of the significant indicator words for each research cluster).

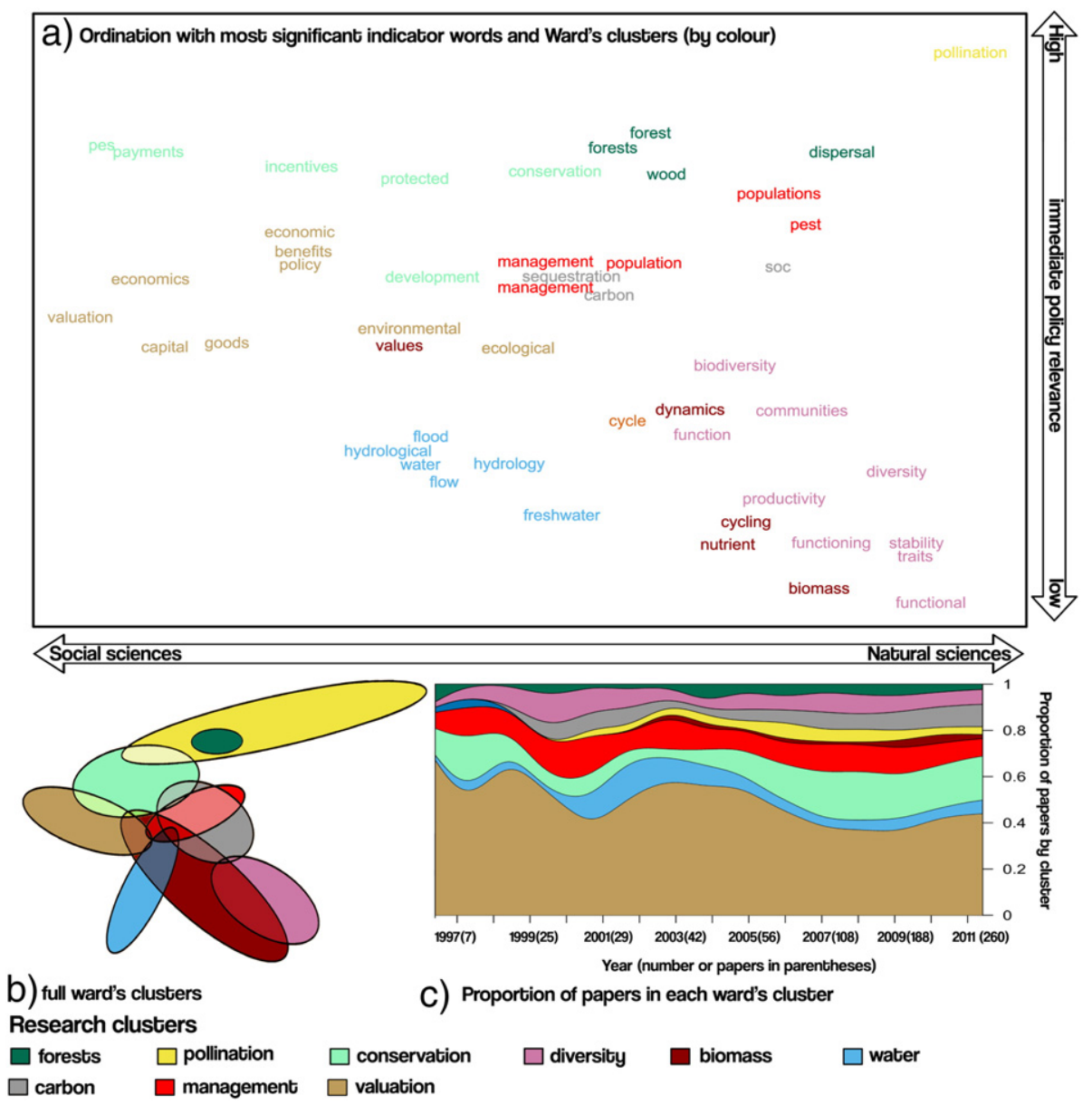

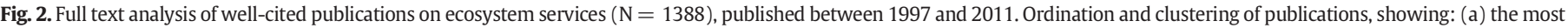

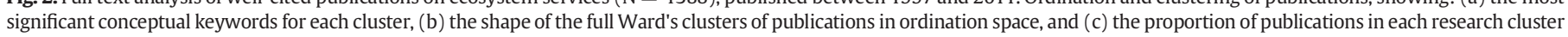
by year. Research clusters near one another shared a larger set of conceptual keywords. 
Valuation (606 publications): This research cluster has a strong theoretical and discursive element, with emphasis on the relationships between ecosystems and human well-being. The publications often address the theoretical and practical challenges of valuing and managing ecosystem services and tend to favour general rather than contextspecific models and frameworks. Empirical studies are dominated by social science and, to a lesser extent, interdisciplinary research, with relatively little focus on ecological processes or functions.

Conservation (232 publications): This research cluster relates ecosystem services maintenance to biodiversity conservation agendas, with many publications addressing payments for ecosystem services, ecological restoration programmes or the potential trade-offs/ complementarities between conservation and human well-being. As with the valuation research cluster, a strong focus is on discussion and agenda setting and less focus on empirical research. Empirical research in this cluster addresses many of the same issues as in the valuation research cluster (management of human-nature interactions), but tends to have a more context specific focus and lower reliance on economic valuation.

Management (140 publications): This research cluster deals with invasive species, pests, biological control and landscape heterogeneity, often in the context of agro-ecological and agricultural intensification. The relations between biodiversity, resilience, and agricultural or fisheries yields are explored with a strong conceptual bias towards ecological functions and processes. There is a relatively strong bias towards natural science approaches in the empirical research.

Carbon (102 publications): This research cluster is one of the most diverse in terms of the balance between empirical and discussion publications and between natural and social science approaches. The focus is largely on the mapping and evaluation of carbon sequestration (in soils and biomass) and the modelling of carbon fluxes in various ecological processes. Economic valuation of carbon fluxes tends not to engage in the dynamic models developed in the biophysical analysis.

Diversity (98 publications): This research cluster is heavily biased towards empirical natural sciences approaches. It deals with ecological communities, and is interested in how functional traits relate to biodiversity, ecosystem functions and ecosystem processes. There is very little focus on human well-being and a strong focus on fundamental science.

Water (78 publications): This research cluster shares a focus on hydrological processes and is driven primarily by problems rather than methods or theory. The domain is relatively evenly balanced between discussion publications and empirical research, with a broad mixture of different scientific disciplines contributing to the body of literature.

Pollination ( 55 publications): A clear focus on pollinator decline and pollination services to agricultural production. This research cluster is dominated by empirical natural science lead research. The tendency is to focus on issues of agroecological management and conservation, with relatively few explicit attempts to place ascribed values on the pollination services that are investigated.

Forests (50 publications): This research cluster, much like the water cluster, takes its focus based on the system under study (mainly tropical forest ecosystems). This cluster is heavily biased towards the natural sciences, including studies on seed dispersal and pollination (the conceptual crossover between this focus and the pollination research focus can be seen in Fig. 2b).

Biomass (27 publications): This is the smallest and a relatively new research cluster, with a strong empirical and natural science bias. The focus is on nutrient cycling, biomass, primary production and soils and system dynamics. While some publications discuss the impacts of biophysical processes on human well-being such relations are rarely quantified.

The strength of the clustering suggested that each of the clusters was relatively self-contained, primarily engaging with its own conceptual vocabulary. Exceptions occurred near the centre of the ordination space. Clusters such as "carbon" and "water" were less focused on specific disciplines, drew on concepts from both natural and social science perspectives, and tended to be problem-oriented or systemsfocused (Fig. 2b). The research clusters at the centre of the ordination were also those-based on a subjective reading of the abstracts-that showed the highest diversity in the subjective classifications of the publication (i.e. a greater mixture of social sciences, natural sciences and interdisciplinary approaches (Table 1 ).

An analysis of temporal trends showed that the domination of ecosystem services research by valuation studies has decreased through time, and research on ecosystem services has become increasingly diverse (Fig. 2c). The 1388 publications analysed were published in a total of 309 journals. However, only $12 \%$ of the journals $(n=39)$ published well cited publications on ecosystem services representing four or more research clusters, whereas $60 \%$ of journals $(n=183)$ published publications in only one research cluster.

\subsection{Journal and Average Citation Analysis}

The (well cited) publications analysed here appeared in 309 different journals, with Ecological Economics publishing $12 \%$ of all publications; $50 \%$ of the publications were published in just 22 journals, and $75 \%$ in 68 journals (Table 2 ); 164 journals published only a single well cited ecosystem services publication between 1997 and 2011.

Only $11 \%$ of journals published well cited, primary focus, ecosystem service research in more than three of the research clusters. Sixty per cent of journals published publications only in one research cluster and a further $28 \%$ in only two research clusters. Twenty-nine journals (8\%) published studies that fell into five or more different knowledge domains (Supplementary Materials Fig. S2). The median number of research clusters in which a given journal publishes is 1 . This suggests a clear separation of the different research clusters, with a high level of specialisation amongst journals publishing ecosystem services research.

Average citations per year, by research cluster indicated higher citation rates in the more natural science focused clusters than in the more social science or interdisciplinary clusters. The water and biomass clusters had the lowest (in part probably a reflection on the size of their related research communities; Supplementary Materials Fig. S3). Despite generating a relatively small body of research the pollinator research cluster is particularly heavily cited, suggesting that the citations were largely from outside the research cluster itself.

\section{Ecosystem Services and Sustainability}

We used a typography of three knowledge types relevant to sustainability (Fig. 3) (ProClim - Forum for Climate and Global Change, 1997). Systems knowledge relates to a descriptive understanding of social and ecological system functioning, including social-ecological interactions and the current and potential future flows of ecosystem services from those interactions. Systems knowledge needs to be interdisciplinary, integrating knowledge from multiple research strands that engage with ecosystem services. Normative knowledge relates to judgements of how a system ought to be. Normative knowledge encompasses both knowledge on desired system states (normative goals or target knowledge (ProClim - Forum for Climate and Global Change, 1997)) and knowledge related to the rationalization of value judgements associated with evaluating alternative potential states of the world (as informed by systems knowledge; Jax et al., 2013; Wiek et al., 2011). Finally, transformative knowledge is needed to develop tangible strategies to manage ecosystems (based on systems knowledge) towards the societal goals derived from normative knowledge (Dobson, 1998; Norton, 2005). Transformative knowledge relates not only to specific policy interventions, but also encompasses more general strategies such as participation, empowerment, education and communication.

To analyse the relation between ecosystem services and sustainability, we used an "expert", top-down, consensual process to identify vocabulary related to different aspects of sustainability. An initial 
Table 1

Relations between research clusters and subjective classification of publications.

\begin{tabular}{|c|c|c|c|c|}
\hline $\begin{array}{l}\text { Research cluster } \\
\text { (number of publications) }\end{array}$ & Discussion/theory/reviews \% & Natural science empirical/modelling \% & Social science empirical/modelling \% & Interdisciplinary empirical/modelling \% \\
\hline Biomass (27) & 0.0 & 81.5 & 11.1 & 7.4 \\
\hline Carbon (102) & 26.5 & 38.2 & 28.4 & 6.9 \\
\hline Conservation (232) & 54.3 & 9.9 & 28.0 & 7.8 \\
\hline Diversity (98) & 33.7 & 59.2 & 1.0 & 6.1 \\
\hline Forests (49) & 14.3 & 69.4 & 12.2 & 4.1 \\
\hline Management (141) & 39.7 & 40.4 & 9.9 & 9.9 \\
\hline Pollination (55) & 23.6 & 61.8 & 7.3 & 7.3 \\
\hline Valuation (606) & 55.1 & 8.4 & 26.7 & 9.7 \\
\hline Water (78) & 47.4 & 34.6 & 10.3 & 7.7 \\
\hline Total (1388) & 45.6 & 24.9 & 21.0 & 8.5 \\
\hline
\end{tabular}

vocabulary of 707 words potentially related to sustainability was produced by the lead author. Co-authors selected those words that they deemed useful indicator words for some aspect of sustainabilityrelevant knowledge, namely systems knowledge, normative knowledge and transformative knowledge. Where four or more co-authors agreed to the inclusion and categorisation of a given word it was included in the final sustainability vocabulary, which left a sustainability vocabulary of 265 words (Supplementary Materials, Table S2). We used the abundance of sustainability vocabulary in individual publications to quantify the relative emphasis within each research cluster on the three types of sustainability-relevant knowledge. We note that the presence of sustainability vocabulary in a given publication is no guarantee that it explicitly engages with the notion of sustainability. However, $85 \%$ of the 1388 publications analysed explicitly mentioned sustainability or sustainable development. We therefore assumed that the presence of sustainability-related vocabulary provided a reasonable (albeit imperfect) indication of engagement with key aspects of sustainability.

Our analyses showed that there was a greater emphasis on systems knowledge than on normative knowledge or transformative knowledge (Figs. 4,5 ). The percentage of sustainability vocabulary that were related to the three sustainability knowledge types found in publications within each of the nine research clusters differed considerably (Fig. 4). In general, the proportion of conceptual keywords used in the publications was relatively low, with publications in the carbon, management and valuation clusters tending to use a broader range of words than in the other clusters (particularly in terms of normative and transformative knowledge).

The sustainability vocabulary was further subdivided into key concerns within each of the three knowledge types (Fig. 5). Almost all publications within all research clusters used vocabulary related to systems functioning and conservation. However, less than $50 \%$ of publications within the forests, biomass, diversity and pollination clusters used any vocabulary related to human well-being, and the diversity, pollination and biomass clusters showed relatively little engagement with vocabulary related to transformative knowledge. Vocabulary related to justice and ethics-concepts essential for making normative judgements on the management of ecosystem services-were found in relatively few publications (Fig. 5). Despite a lack of explicit engagement with justice and ethics, policy and governance vocabulary was prominent in many research clusters. The clusters occupying the centre of the ordination-

Table 2

The 30 journals with the highest number of well cited ecosystem services publications published from 1997 to 2011.

\begin{tabular}{|c|c|c|c|c|c|c|c|c|c|c|}
\hline \multirow[b]{2}{*}{ Journal } & \multicolumn{10}{|c|}{ Research clusters } \\
\hline & Valuation & Conservation & Management & Carbon & Diversity & Water & Pollination & Forests & Biomass & Total publications \\
\hline Ecological Economics & 113 & 30 & 4 & 8 & 1 & 6 & 2 & 0 & 2 & 166 \\
\hline Ecological Applications & 15 & 7 & 10 & 2 & 3 & 1 & 2 & 4 & 2 & 46 \\
\hline Ecology and Society & 24 & 8 & 3 & 0 & 0 & 4 & 0 & 1 & 0 & 40 \\
\hline PNAS & 9 & 12 & 4 & 5 & 5 & 0 & 3 & 1 & 0 & 39 \\
\hline Journal of Applied Ecology & 4 & 6 & 9 & 2 & 4 & 0 & 7 & 3 & 1 & 36 \\
\hline Frontiers in Ecology and the Environment & 16 & 4 & 2 & 3 & 1 & 2 & 0 & 0 & 0 & 28 \\
\hline Agriculture, Ecosystems and Environment & 8 & 4 & 4 & 1 & 8 & 0 & 2 & 1 & 0 & 28 \\
\hline Conservation Biology & 9 & 12 & 3 & 0 & 1 & 0 & 0 & 2 & 0 & 27 \\
\hline Biodiversity and Conservation & 10 & 11 & 1 & 0 & 1 & 0 & 1 & 1 & 0 & 25 \\
\hline Biological Conservation & 8 & 7 & 4 & 0 & 0 & 0 & 4 & 1 & 0 & 24 \\
\hline Forest Ecology and Management & 1 & 4 & 1 & 7 & 0 & 0 & 0 & 11 & 0 & 24 \\
\hline Journal of Environmental Management & 14 & 5 & 2 & 3 & 0 & 0 & 0 & 0 & 0 & 24 \\
\hline BioScience & 11 & 5 & 3 & 1 & 1 & 2 & 0 & 0 & 0 & 23 \\
\hline Environmental Management & 12 & 3 & 4 & 1 & 0 & 3 & 0 & 0 & 0 & 23 \\
\hline Ecological Modelling & 14 & 0 & 2 & 2 & 0 & 1 & 1 & 1 & 1 & 22 \\
\hline Ecology Letters & 7 & 2 & 4 & 0 & 2 & 0 & 6 & 0 & 0 & 21 \\
\hline Ecosystems & 9 & 1 & 1 & 1 & 3 & 2 & 0 & 1 & 1 & 19 \\
\hline Environmental Conservation & 8 & 11 & 0 & 0 & 0 & 0 & 0 & 0 & 0 & 19 \\
\hline Ecological Complexity & 14 & 2 & 0 & 0 & 0 & 1 & 0 & 0 & 1 & 18 \\
\hline Environmental and Resource Economics & 8 & 4 & 1 & 1 & 0 & 0 & 0 & 0 & 1 & 15 \\
\hline Environmental Science and Policy & 7 & 2 & 0 & 5 & 0 & 0 & 0 & 0 & 0 & 14 \\
\hline Global Environmental Change & 8 & 2 & 1 & 2 & 0 & 1 & 0 & 0 & 0 & 14 \\
\hline Landscape and Urban Planning & 8 & 2 & 3 & 1 & 0 & 0 & 0 & 0 & 0 & 14 \\
\hline Science & 7 & 3 & 0 & 1 & 1 & 0 & 2 & 0 & 0 & 14 \\
\hline Philosophical Transactions of the Royal Society B: & 4 & 4 & 1 & 1 & 1 & 1 & 0 & 0 & 1 & 13 \\
\hline Trends in Ecology and Evolution & 8 & 0 & 1 & 0 & 2 & 0 & 2 & 0 & 0 & 13 \\
\hline Ambio & 9 & 1 & 1 & 0 & 0 & 1 & 0 & 0 & 0 & 12 \\
\hline Ecology & 2 & 1 & 1 & 0 & 7 & 0 & 1 & 0 & 0 & 12 \\
\hline PLOS ONE & 4 & 2 & 1 & 0 & 1 & 1 & 3 & 0 & 0 & 12 \\
\hline Environmental Science and Technology & 9 & 0 & 0 & 1 & 0 & 1 & 0 & 0 & 0 & 11 \\
\hline
\end{tabular}




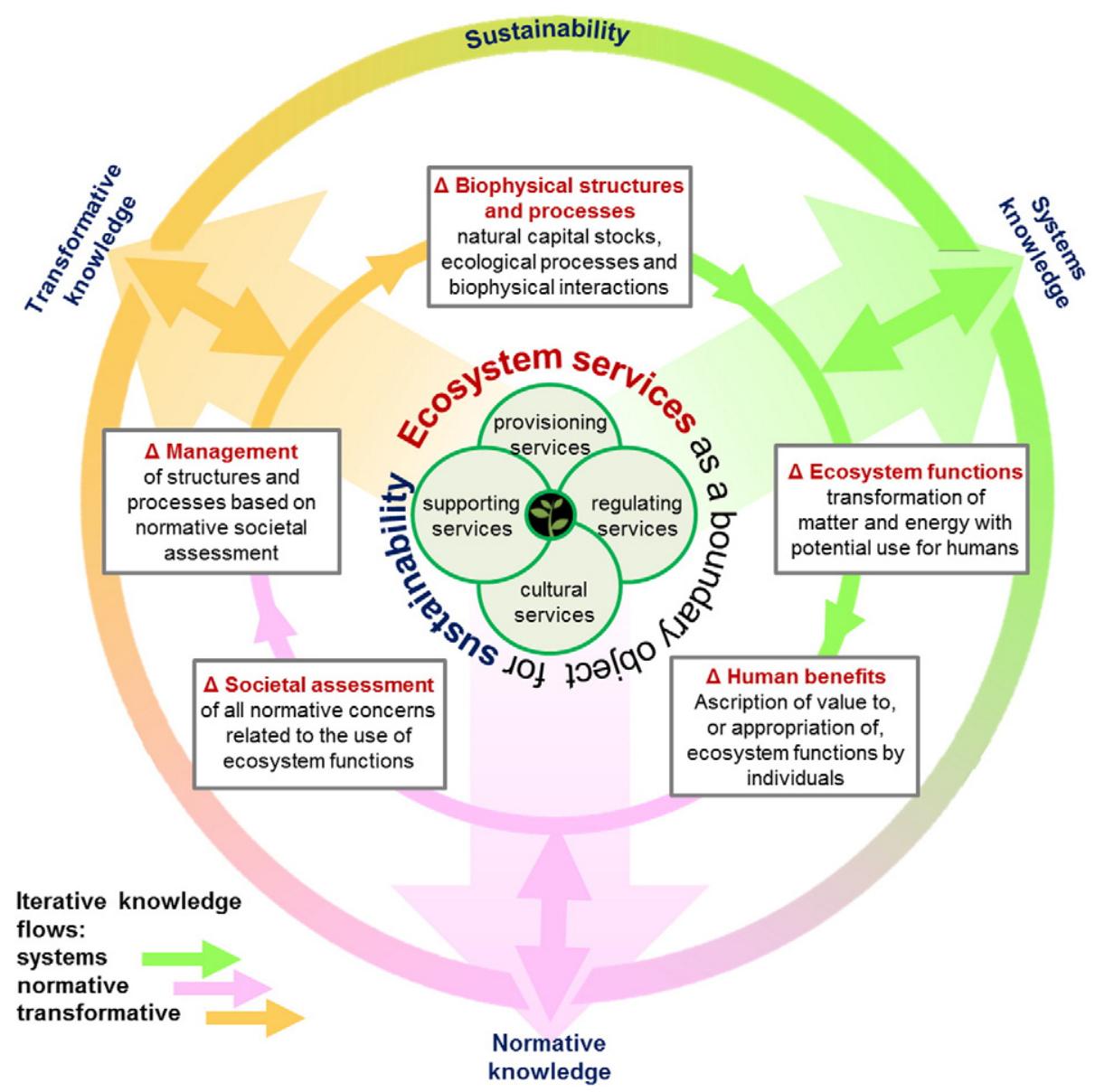

Fig. 3. Relations between ecosystem services and three types of knowledge relevant to sustainability.

conservation, water and management and the valuation research cluster (Fig. 2)-engaged in the most balanced way with systems, normative and transformative knowledge (Fig. 5).

In terms of temporal trends, transformative knowledge has become more important over time relative to systems and normative knowledge. Within normative knowledge, a small shift has occurred away from "justice \& ethics" towards "efficiency". Within transformative knowledge, a shift occurred away from "education" towards "transformation" (Supplementary Materials Fig. S4).

\section{Future Priorities for Ecosystem Services Research}

Ecosystem services research is a rapidly diversifying field published across a broad range of different journals and engaging multiple scientific disciplines. The term "ecosystem services" is increasingly used in publications not primarily interested in the concept itself, suggesting that it is becoming an increasingly mainstream and accepted idea within the broader scientific community. Within a sustainability context, our analysis points to three critical challenges for the future development of the ecosystem services concept as it moves from being primarily a heuristic model towards becoming an explicit management tool: better interdisciplinary knowledge integration, greater focus on normative knowledge, and improved recognition of the ecosystem services concept as a potential transformative tool.

\subsection{Better Interdisciplinary Knowledge Integration}

The growth in ecosystem services research between 1997 and 2011 drew in a growing diversity of disciplinary expertise. However, we found considerable compartmentalisation of research. Within publications primarily focusing on ecosystem services, there were distinct research clusters with their own conceptual vocabularies. The considerable conceptual distance between some of these research clusters (Fig. 2) suggests a lack of shared focus, terminology and systems representations within this broad research field. Given the inherently interdisciplinary nature of the ecosystem services concept (Collins et al., 2011), such fragmentation of knowledge is potentially problematicparticularly because systems knowledge related to ecosystem services must integrate a wide range of complex relations and feedbacks between social and ecological functions (Chee, 2004; Nicholson et al., 2009).

A common understanding derived from, and expressed through, shared vocabularies plays a vital role in facilitating interdisciplinary knowledge integration (Bracken and Oughton, 2006; Lang et al., 2012). A complete turnover of conceptual keywords along both axes of the ordination (Fig. 2) suggested that there was little shared focus between natural science and social science research, and between ecosystem services research with immediate policy relevance versus more fundamental research. The biomass and pollinator research clusters were particularly interesting-despite both clusters being largely driven by the natural sciences, they appear to have "stretched" themselves and engage with concepts and ideas outside their core disciplines. Despite such exceptions, overall, our findings suggest that a shared conceptual vocabulary has not yet emerged within the field of ecosystem services research. Norgaard (2010) has suggested that the ecosystem services concept is a "complexity blinder". In contrast our findings suggest that the breadth of self-identified ecosystem services research is not blind to the complexities of human-environmental interactions, but rather, 

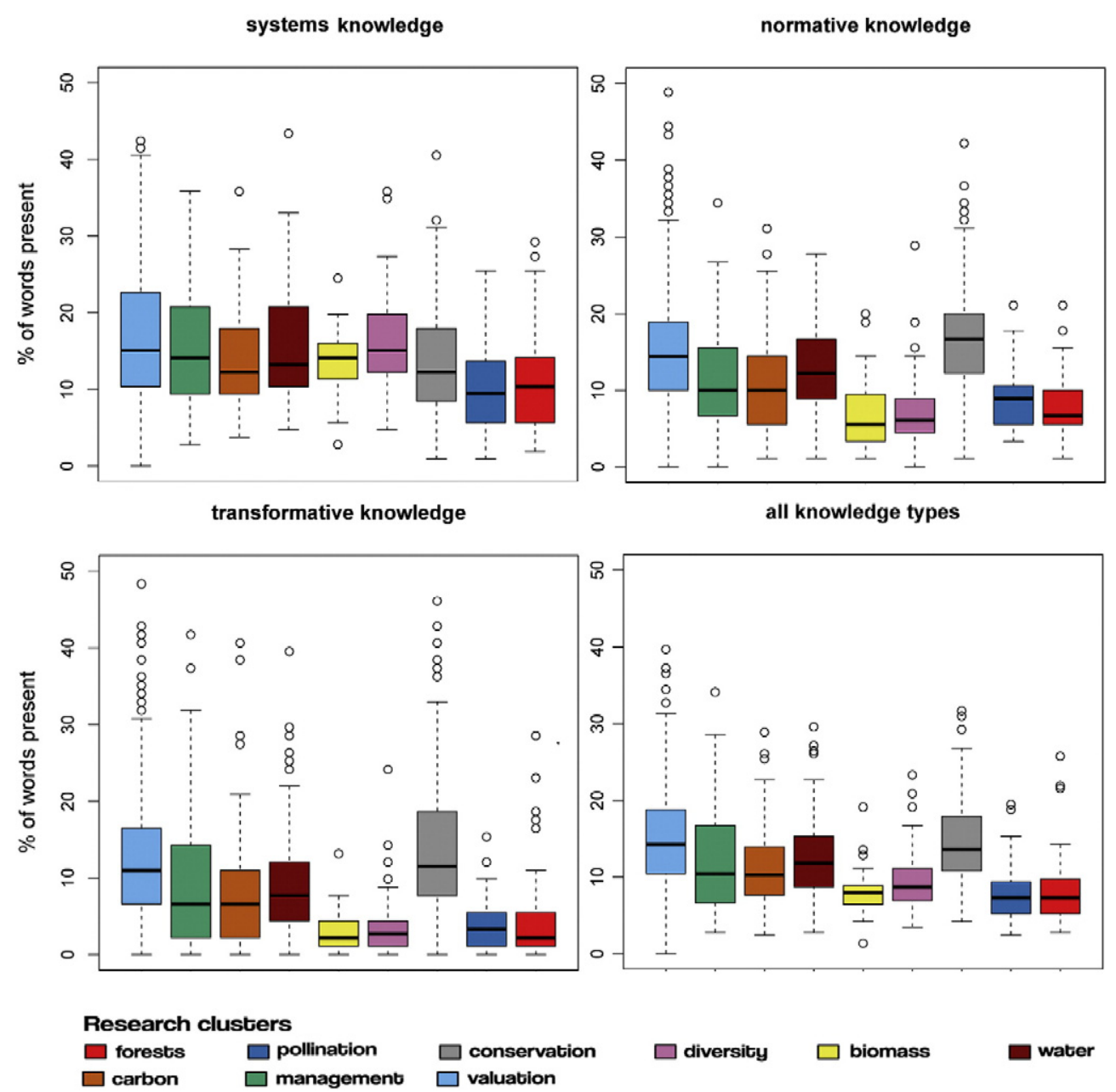

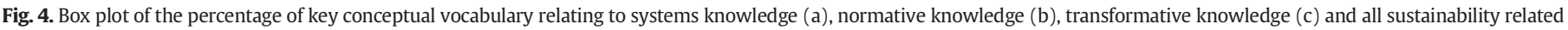

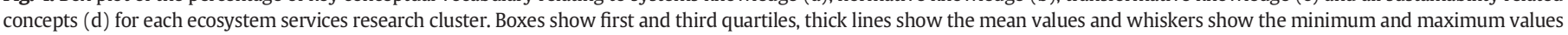
(circles represent outliers).

the complexities discussed in the different ecosystem services research foci have not yet been integrated into a shared understanding or operationalization of the concept.

\subsection{Greater Focus on Normative Knowledge}

Through its focus on the link between biodiversity conservation and human well-being, a large amount of literature on ecosystem services has inescapably normative dimensions. The linkage between the concept of ecosystem services and sustainability is relatively well established in the ecosystem services literature (albeit implicitly and vaguely at times). However, our findings suggest that few publications on ecosystem services engage deeply with normative issues. This relative lack of explicit discussion of justice and ethics within ecosystem service research is a cause of potential concern. Several researchers have identified the importance of ethical concerns within the framing of the ecosystems services debate (Ghazoul, 2007; Glotzbach and Baumgärtner, 2012; Gomiero et al., 2010; Jax et al., 2013; Reyers et al., 2010), and in the context of managing trade-offs between human well-being and biodiversity conservation (Chan et al., 2006; McShane et al., 2011). While descriptive, systems knowledge is undoubtedly important, an increasingly detailed understanding of systems dynamics does not provide the necessary tools for societal judgements regarding whether specific changes can be deemed "good". A danger therefore remains that judgements regarding the "good" management of ecosystems are based on implicit normative assumptions built into particular research approaches used in ecosystem services research (e.g. choice of study system, monetary valuation) (McShane et al., 2011). Normative knowledge can help ensure that systems descriptions are meaningful in the context of achieving the societal goals and to avoid the pitfall of the ecosystem services concept becoming a technocratic discourse (Abson and Hanspach, 2013; Turnhout et al., 2013). On this basis, we argue that, in the future, judgements regarding the management of ecosystem services and potential trade-offs between services should be based on explicitly defined normative frameworks.

There is not a single accepted normative framework through which such ecosystem services trade-offs should be addressed, nor do we suggest that there should be one. Rather we argue that explicit regard for normative issues (which may be framed in multiple ways, drawing on different philosophical perspectives) would both broaden and deepen our understanding of the role of the ecosystem services concept in relation to the broader societal goal of sustainability.

\subsection{Ecosystem Services as a Transformative Tool}

Daily et al. (Daily et al., 2009) called for an improved development of the scientific basis and of necessary policy mechanisms to facilitate the large-scale application of the ecosystem services concept in decision making. Consistent with this, our analysis suggests that there has been considerable effort to develop systems knowledge relating to ecosystem services. Moreover, calls for the use of the ecosystem services concept as a policy and decision tool (Bateman et al., 2013; Daily et al., 2009; 


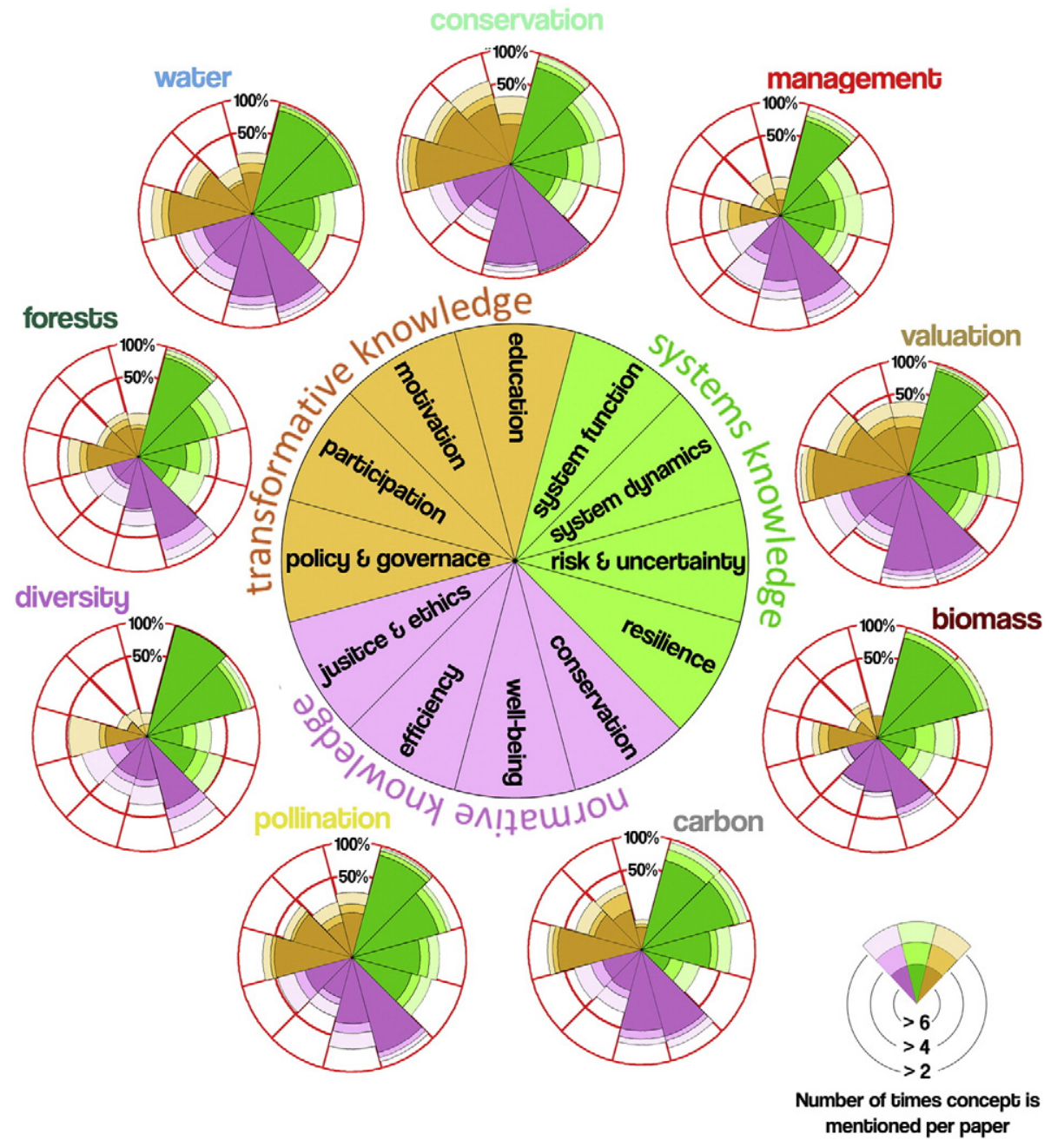

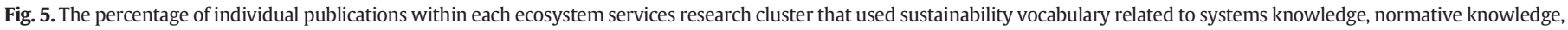

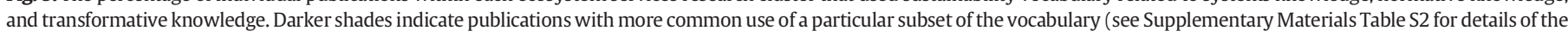
sustainability vocabulary considered).

Wainger et al., 2010) are reflected in the literature by a substantial number of publications in different research clusters that use language related to policy and decision making (Fig. 5).

However, our analysis also suggests that, in a sustainability context, knowledge on systems dynamics and policy mechanisms is not sufficient. Rather, the current emphasis on systems understanding and policy (Figs. 4,5) needs to be matched by transformative knowledge that relates explicitly stated normative goals (which may vary across space, time and institutional scales) to the processes required to achieve those goals. The ecosystem services concept has the potential to act as a transdisciplinary boundary object, engaging different disciplines and non-scientists in shaping and achieving societal goals (Reyers et al., 2010). In this context, the ecosystem services concept could be instrumental in facilitating transformative processes in society that help create more sustainable human-nature relations. While the ecosystem services concept undoubtedly has the potential to act as a boundary object for sustainability, we argue that at this stage, literature on ecosystem services does not yet encompass the breadth of issues it will ultimately need to cover. As a transformative concept, ecosystem services will need to engage not only with literature on governance, but also with work on engagement, motivation, communication and education-themes that, to date, remain marginal within the ecosystem services literature.

\section{Conclusion}

The three challenges outlined above are tightly interlinked, and advances in one challenge are likely to be, at least partially, contingent on advances in the other two. Our research suggests that problemoriented and systems-based approaches to ecosystem services research (e.g. the water, conservation and management clusters; Fig. 2) as opposed to more traditional disciplinary approaches have most successfully created spaces where the knowledge and understandings from multiple disciplines are being integrated. The problem-oriented and systems-based research clusters also engaged in a more balanced way with the normative, systems and transformative knowledge types than the other research clusters (Fig. 5). A problem-oriented and systems-based focus also could provide opportunities to engage more actively in transdisciplinary research (Baumgärtner et al., 2008; Sherren et al., 2010), where the ecosystem services concept can become a transformative tool for sustainability.

For better or worse, the ecosystem services concept has deeply rooted normative foundations. As ecosystem services research moves into its fourth decade, and is increasingly being promoted as a management tool, there is a need to more fully and carefully consider the role of normative knowledge, in both the conceptualization of ecosystem services as a scientific concept, and as a means of guiding the enhancement of 
both systems knowledge and transformative knowledge. In doing so, we believe that ecosystem services can further consolidate its place as a key concept in the service of creating a more sustainable world.

\section{Acknowledgements}

JF was supported by a Sofja Kovalevskaja Award, granted by the Alexander von Humboldt Foundation and financed by the German Ministry of Education and Research. AMK and DW were supported by the European Regional Development Fund (ERDF), the Federal State of Lower Saxony and the Leuphana University Innovation Incubator.

\section{Appendix A. Supplementary data}

Supplementary data to this article can be found online at http://dx. doi.org/10.1016/j.ecolecon.2014.04.012.

\section{References}

Abson, D.J., Hanspach, J., 2013. Response to Turnhout et al.'s rethinking biodiversity: from goods and services to "living with". Conserv. Lett. http://dx.doi.org/10.1111/conl. 12059.

Balmford, A., Fisher, B., Green, R.E, Naidoo, R., Strassburg B. Turner, R. K, Rodrigues, A.S.L, 2011. Bringing ecosystem services into the real world: an operational framework fo assessing the economic consequences of losing wild nature. Environ. Resource Econ 48, 161-175.

Bateman, I.J., Harwood, A.R., Mace, G.M., Watson, R.T., Abson, D.J., Andrews, B., Binner, A. Crowe, A., Day, B.H., Dugdale, S., Fezzi, C., Foden, J., Hadley, D., Haines-Young, R., Hulme, M., Kontoleon, A., Lovett, A.A., Munday, P., Pascual, U., Paterson, J., Perino, G. Sen, A., Siriwardena, G., Van Soest, D., Termansen, M., 2013. Bringing ecosystem services into economic decision-making: land use in the United Kingdom. Science 341 $45-50$.

Baumgärtner, S., Becker, C., Frank, K., Müller, B., Quaas, M.F., 2008. Relating the philosophy and practice of ecological economics. The role of concepts, models and case studies in inter- and transdisciplinary sustainability research. Ecol. Econ. 67, 384-393.

Bracken, L.J., Oughton, E.A., 2006. 'What do you mean?' The importance of language in developing interdisciplinary research. Trans. Inst. Br. Geogr. 31, 371-382.

Callicott, J.B., Crowder, L.B., Mumford, K., 1999. Current normative concepts in conservation. Conserv. Biol. 13, 22-35

Chan, K.M.A., Shaw, M.R., Cameron, D.R., Underwood, E.C., Daily, G.C., 2006. Conservation planning for ecosystem services. PLoS Biol. 4, 2138-2152.

Chee, Y.E., 2004. An ecological perspective on the valuation of ecosystem services. Biol Conserv. 120, 549-565.

Collins, S.L., Carpenter, S.R., Swinton, S.M., Orenstein, D.E., Childers, D.L., Gragson, T.L., Grimm, N.B., Morgan, G.J., Harlan, S.L., Kaye, J.P., Knapp, A.K., Kofinas, G.P., Magnuson, J.J., McDowell, W.H., Melack, J.M., Ogden, L.A., Philip, R.G., Smith, M.D. Whitmer, A.C., 2011. An integrated conceptual framework for long-term socialecological research. Front. Ecol. Environ. 9, 351-357.

Costanza, R., 2000. Social goals and the valuation of ecosystem services. Ecosystems 3 , 4-10.

Costanza, R., dArge, R., deGroot, R., Farber, S., Grasso, M., Hannon, B., Limburg, K., Naeem, S., Oneill, R.V., Paruelo, J., Raskin, R.G., Sutton, P., vandenBelt, M., 1997. The value of the world's ecosystem services and natural capital. Nature 387, 253-260.

Daily, G., 1997. Nature's Services: Societal Dependence on Natural Ecosystems. Island Press, Washington D.C.

Daily, G.C., Polasky, S., Goldstein, J., Kareiva, P.M., Mooney, H.A., Pejchar, L., Ricketts, T.H., Salzman, J., Shallenberger, R., 2009. Ecosystem services in decision making: time to deliver. Front. Ecol. Environ. 7, 21-28.

de Groot, R.S., 1987. Environmental functions as a unifying concept for ecology and economics. Environmentalist 7, 105-109.

de Groot, R.S., Alkemade, R., Braat, L., Hein, L., Willemen, L., 2010. Challenges in integrating the concept of ecosystem services and values in landscape planning, management and decision making. Ecol. Complex. 7, 260-272.

Dobson, A., 1998. Justice and the Environment. Conceptions of Environmental Sustainability and Dimensions of Social Justice. Oxford University Press, Oxford.

Dufrene, M., Legendre, P., 1997. Species assemblages and indicator species: the need for a flexible asymmetrical approach. Ecol. Monogr. 67, 345-366.

Ehrlich, P.R., Ehrlich, A., 1981. Extinction: The Causes and Consequences of the Disappearance of Species. Random House, New York.

Ehrlich, P.R., Mooney, H., 1983. Extinction, substitution, and ecosystem services. Bioscience $33,248-254$
Engel, S., Pagiola, S., Wunder, S., 2008. Designing payments for environmental services in theory and practice - an overview of the issues. Ecol. Econ. 65, 663-674.

Ghazoul, J., 2007. Recognising the complexities of ecosystem management and the ecosystem service concept. Gaia-Ecol. Perspect. Sci. Soc. 16, 215-221.

Gibson, R.B., 2006. Beyond the pillars: sustainability assessment as a framework for effective integration of social, economic and ecological considerations in significant decision-making. J. Environ. Assess. Pol. Manag. 08, 259-280.

Glotzbach, S., Baumgärtner, S., 2012. The relationship between intragenerational and intergenerational ecological justice. Environ. Values 21, 331-355.

Gómez-Baggethun, E., de Groot, R., Lomas, P.L., Montes, C., 2010. The history of ecosystem services in economic theory and practice: from early notions to markets and payment schemes. Ecol. Econ. 69, 1209-1218.

Gomiero, T., Paoletti, M.G., Pimentel, D., 2010. Biofuels: efficiency, ethics, and limits to human appropriation of ecosystem services. J. Agric. Environ. Ethics 23, 403-434.

Jax, K., Barton, D.N., Chan, K.M.A., de Groot, R., Doyle, U., Eser, U., Görg, C., GómezBaggethun, E., Griewald, Y., Haber, W., Haines-Young, R., Heink, U., Jahn, T., Joosten, H., Kerschbaumer, L., Korn, H., Luck, G.W., Matzdorf, B., Muraca, B., Neßhöver, C., Norton, B., Ott, K., Potschin, M., Rauschmayer, F., von Haaren, C., Wichmann, S., 2013. Ecosystem services and ethics. Ecol. Econ. 93, 260-268.

Kinzig, A.P., Perrings, C., Chapin III, F.S., Polasky, S., Smith, V.K., Tilman, D., Turner II, B.L., 2011. Paying for ecosystem services - Promise and peril. Science 334, 603-604.

Kumar, P., 2010. In: Kumar, P. (Ed.), The Economics of Ecosystems and Biodiversity (TEEB): Ecological and Economic Foundations. Earthscan, London.

Lang, D.J., Wiek, A., Bergmann, M., Stauffacher, M., Martens, P., Moll, P., Swilling, M., Thomas, C.J., 2012. Transdisciplinary research in sustainability science: practice, principles, and challenges. Sustain. Sci. 7, 25-43.

MA, 2005. Ecosystems and Human Well-being: Current State and Trends. Island Press, Washington, DC.

Maes, J., Egoh, B., Willemen, L., Liquete, C., Vihervaara, P., Schägner, J.P., Grizzetti, B. Drakou, E.G., Notte, A.L., Zulian, G., Bouraoui, F., Paracchini, M.L., Braat, L., Bidoglio, G., 2012. Mapping ecosystem services for policy support and decision making in the European Union. Ecosyst. Serv. 1, 31-39.

McShane, T.O., Hirsch, P.D., Trung, T.C., Songorwa, A.N., Kinzig, A., Monteferri, B., Mutekanga, D., Thang, H.V., Dammert, J.L., Pulgar-Vidal, M., Welch-Devine, M., Brosius, J. Peter, Coppolillo, P., O'Connor, S., 2011. Hard choices: making trade-offs between biodiversity conservation and human well-being. Biol. Conserv. 144, 966-972.

Nicholson, E., MacE, G.M., Armsworth, P.R., Atkinson, G., Buckle, S., Clements, T., Ewers, R. M., Fa, J.E., Gardner, T.A., Gibbons, J., Grenyer, R., Metcalfe, R., Mourato, S., Muûls, M., Osborn, D., Reuman, D.C., Watson, C., Milner-Gulland, E.J., 2009. Priority research areas for ecosystem services in a changing world. J. Appl. Ecol. 46, 1139-1144.

Norgaard, R.B., 2010. Ecosystem services: from eye-opening metaphor to complexity blinder. Ecol. Econ. 69, 1219-1227.

Norton, B.G., 2005. Sustainability: A Philosophy of Adaptive Ecosystem Management. University of Chicago Press, London.

Peterson, M.J., Hall, D.M., Feldpausch-Parker, A.M., Peterson, T.R., 2010. Obscuring ecosystem function with application of the ecosystem services concept. Conserv. Biol. 24, 113-119.

ProClim - Forum for Climate and Global Change, 1997. Research on Sustainability and Global Change - Visions in Science Policy by Swiss Researchers.

R Core Team, 2012. R: A Language and Environment for Statistical Computing. R Foundation for Statistical Computing, Vienna, Austria.

Reyers, B., Roux, D.J., O'Farrell, P.J., 2010. Can ecosystem services lead ecology on a transdisciplinary pathway? Environ. Conserv. 37, 501-511.

Schröter, M., van der Zanden, E.H., van Oudenhoven, A.P.E., Remme, R.P., Serna-Chavez, H. M., de Groot, R.S., Opdam, P., 2014. Ecosystem services as a contested concept: a synthesis of critique and counter-arguments. Conserv. Lett. http://dx.doi.org/10.1111/ conl.12091.

Sherren, K., Fischer, J., Clayton, H., Schirmer, J., Dovers, S., 2010. Integration by case, place and process: transdisciplinary research for sustainable grazing in the Lachlan River catchment, Australia. Landsc. Ecol. 25, 1219-1230. http://dx.doi.org/10.1007/ s10980-010-9494-x

Star, S.L., Griesemer, J.R., 1989. Institutional ecology, 'translations' and boundary objects: amateurs and professionals in Berkeley's museum of vertebrate zoology, 1907-39. Soc. Stud. Sci. 19, 387-420.

Toman, M.A., 1994. Economics and 'sustainability': balancing trade-offs and imperatives. Land Econ. 70, 399-413.

Turnhout, E., Waterton, C., Neves, K., Buizer, M., 2013. Technocratic and economic ideals in the ecosystem services discourse. Conserv. Lett. http://dx.doi.org/10.1111/conl. 12069.

Wainger, L.A., King, D.M., Mack, R.N., Price, E.W., Maslin, T., 2010. Can the concept of ecosystem services be practically applied to improve natural resource management decisions? Ecol. Econ. 69, 978-987.

Westman, W.E., 1977. How much are nature's services worth? Science 197, 960-964.

Wiek, A., Withycombe, L., Redman, C.L., 2011. Key competencies in sustainability: a reference framework for academic program development. Sustain. Sci. 6, 203-218.

Wilson, M.A., Howarth, R.B., 2002. Discourse-based valuation of ecosystem services: establishing fair outcomes through group deliberation. Ecol. Econ. 41, 431-443. 